\title{
Proceedings of the XXIVth Congress of the International Primatological Society \\ Cancun, Mexico August 12-18, 2012
}

\author{
Nancy Caine
}

Received: 20 January 2013 / Accepted: 22 January 2013 / Published online: 23 February 2013

(C) Springer Science+Business Media New York 2013

\section{Minutes from the Pre-Congress Meeting of the Council of the International Primatological Society August 12, 2012}

Attending:

IPS Officers:

Juichi Yamagiwa (President, also representing Primate Society of Japan)

Nancy Caine (Secretary General)

Katie Leighty (VP for Communications)

Elizabeth Lonsdorf (VP for Education)

Debby Cox (VP for Captive Care and Breeding)

Steve Schapiro (Treasurer and VP for Membership)

Janette Wallis (VP for Conservation)

Jo Setchell (VP for Research and Editor-in-Chief of International Journal of Primatology)

Affiliated Society representatives:

Catarina Casanova (Associação Portuguesa de Primatologia)

Paul Honess (Primate Society of Great Britain)

Dorothy Fragaszy (American Society of Primatologists)

Maria Adelia B. de Oliveira and Mauricio Talebi (Sociedade Brasileira de Primatologia)

Riashna Sithaldeen (Primate Ecology and Genetics Group, South Africa)

Ute Radespiel (Gesellschaft für Primatologie and European Federation of Primatologists)

Gabriel Ramos-Fernandez (Asociación Mexicana de Primatología)

Marco Gamba (Associazione Primatologica Italiana)

Christoph Schwitzer (Primate Specialist Group and incoming VP for Communications)

\footnotetext{
N. Caine $(\bowtie)$

California State University San Marcos, San Marcos, CA, USA

e-mail: ncaine@csusm.edu
} 
I. The meeting was called to order at $12: 10 \mathrm{~h}$ by President Yamagiwa. Introductions were made.

II. Presentation by the organizers of the 2014 Congress in Ha Noi, Vietnam.

A. Nguyen Manh Hiep presented information about the venue, costs, and logistics of the congress that will be held August 11-16 at the Melia Ha Noi Hotel.

B. A webpage describing the congress will be linked to the IPS website in October, 2012, and will be updated frequently as the congress approaches. The URL will be www.primatecongress2014.vn

III. President's Report

A. In his role as President, Dr. Yamagiwa presided over the Elections Committee, which included Drs. Bernard Thierry, Hannah BuchananSmith, Joan Silk, Nancy Caine, Ryne Palombit, and Augustin Basabose.

1. A slate of two nominees for each of the three offices that were scheduled for election was selected and presented to the membership for a vote.

2. The results: President, Tetsuro Matsuzawa; VP for Communications, Katie Leighty; VP for Education, Elizabeth Lonsdorf; VP for Captive Care, Christoph Schwitzer

3. Soon after the election, Dr. Leighty learned that she must decline the post due to increased responsibilities at her place of work. In accordance with the IPS Constitution, the Council selected Dr. Claudia Fichtel to assume the post, and Dr. Fichtel agreed.

B. Pres. Yamagiwa also presided over the selection of the Lifetime Achievement award. A committee composed of Drs. Carel van Schaik, Dorothy Fragaszy, Jonah Ratsimbazafy, Katherine Leighty, and Nancy Caine reviewed the nominations and selected Dr. John Oates.

\section{Secretary General Report (N. Caine)}

A. It is important for the affiliated societies to keep the Secretary General up-todate in terms of contact information, changes to the officers of the Society, and other pertinent information.

B. New officers will assume their positions at the end of the General Assembly and should attend the post-congress Council meeting if possible.

V. Membership and Finance Report (S. Schapiro)

\section{A. Membership}

1. As of the current congress, membership is down by about 250 from 2010 . We have 1434 members. 
2. Membership is up from the Americas, probably reflecting the location of the 2012 Congress. Membership is down from Asia (following the bulge in Asian membership associated with attendance at the 2010 Congress). European membership is also down.

\section{B. Financial Report}

1. The projected balance in the General Fund at the end of the current year is about $\$ 100,000$.

2. IPS will lose about $\$ 65,000$ on the current congress.

3. Since 2008 we have spent about $\$ 85,000$ a year on grants and, in congress years, the Pre-Congress Training Program.

4. Credit card fees are considerable (about $\$ 5,000$ per year), but most members want the convenience of using credit cards to pay for IPS membership and congress attendance. We hope that new technologies will reduce or eliminate the costs of doing business in the future.

C. Congress registration fees: Can they be reduced?

1. The registration fee is always determined by calculating the total cost of putting on the congress (a number produced by the organizing committee) and dividing by the number of likely registrants (i.e., a break-even budget).

2. A very small percentage of the overall costs associated with attending the meeting is represented by the registration fee.

3. The registration fee for students and registrants from habitat countries is always considerably lower than it is for full members. In this way, those more able to afford to attend a congress are subsidizing those who are less able to afford it.

4. Our fees are in line with those of other, similar organizations.

5. Holding the congress at a university is unlikely to be less expensive than holding the congress at a hotel/conference center, and universities often pose logistical problems. However, the bid document will be edited to include the requirement that potential organizers investigate the possibility of a university venue.

6. Why not give refunds to people who cannot come?

a. We do in fact give refunds if the congress makes a profit. The refund is less administrative costs and no refunds are given if a registrant withdraws within a month of the congress.

b. Despite some concerns that it will encourage people to register without a firm commitment to attend, we will change the refund policy on the congress website, indicating that partial refunds are possible.

D. What is the purpose behind maintaining a large balance in the General Fund?

1. Some congresses are profitable, typically because more people register than we had anticipated, as was true in Uganda, and some are not, typically 
because fewer people register than we had anticipated, as is the case for the current (2012) congress.

2. The general fund balance increased substantially in 2006 following a particularly profitable congress in Uganda and the first wave of lifetime memberships.

3. Profits from congresses, when they occur, allow us to give more to our grants and awards programs and help to establish the financial cushion we need to protect ourselves in cases where we lose money on a congress.

4. D. Fragaszy made the following motion, which was passed unanimously: The IPS Council will communicate with affiliated societies that:

a. It understands and shares concerns about the costs of attending congresses, especially for students and primatologists from range countries.

b. IPS and local organizing committees will continue to work to set congress costs as low as possible, recognizing that many of the costs are out of our control (travel, accommodations, food, fixed venue costs, etc.).

c. All congress budgets are designed to break even, but when profits are realized, IPS is able to fund our grants and training programs; indeed, increased funding to our grants and training programs has followed profitable congresses.

d. The Society is exposed to financial risk associated with the biannual congress.

e. The IPS Council recognizes that it is the Council's responsibility to maintain the fiscal health of the IPS by maintaining a financial reserve to cover unexpected losses associated with congresses. Approximately $50 \%$ of the cost of a typical congress should be maintained as a reserve, when possible.

\section{VP for Conservation Report (J. Wallis)}

A. A very successful Pre-Congress Training Program this year:

1. 127 applicants from which 12 were selected (see the list in the General Assembly minutes)

2. Visas were a problem in a number of cases. All participants were from habitat countries. All are early in their careers.

B. Grants were awarded to 11 applicants in 2011 and 8 applicants in 2012 (see list of names in the General Assembly minutes).

1. Applicants for whom English is not the native language often have trouble putting together a competitive grant application.

2. The committee advertises free assistance to improve the grammar and sentence structure of grants prior to submission, but not a single applicant has availed him- or herself of that service. 
VII. VP for Education Report (E. Lonsdorf)

A. 2012 Congress student paper/poster competition

1. There were 70 entrants for the oral competition from which 9 were selected as finalists. This is slightly smaller than the pool from the Kyoto Congress, probably reflecting the lower congress attendance overall.

2. There were 10 entrants for poster competition; the committee selected 5 finalists.

3. Winners to be announced at General Assembly.

B. Jacobsen and Southwick awards were made in 2011 and 2012 (see list in General Assembly minutes).

C. Thus far in 2011-12, 8 letters have been sent in support of the IPS Position Statement Against Use of Primates in Entertainment. They include letters to Psychology Today, to Science News, and to the makers of the films Hangover and We Bought a Zoo.

D. A letter was composed on behalf of the IPS Council in support of abolishing the US Fish and Wildlife Service split-listing of chimpanzees. The letter encouraged them to list all chimpanzees, regardless of birthplace, as endangered.

E. In accordance with a Council decision in 2010, we advertised in the Bulletin that we were looking for IPS members who were willing to direct their IJP subscriptions to field sites. This was unsuccessful. Should we halt the initiative or advertise it again?

VIII. VP for Captive Care and Breeding Report (D. Cox)

A. Not as many grant submissions as we would like ( $N=16$ in 2012) but many primates benefit.

1. Tend to favor submissions with direct welfare and where large numbers of primates will benefit (e.g., workshops for veterinarians).

B. Translations of the IPS Captive Care Guidelines

1. Mandarin and Japanese are the newest ones; Thai is underway.

2. Seeking funds to support these translations. Some welfare entities (e.g., Humane Society) are not interested in supporting such efforts. Laboratory animal organizations might be more willing.

3. All IPS affiliated societies should have links on their webpage to IPS captive care guidelines. Affiliate representatives will see to this action.

IX. VP for Research Report (J. Setchell)

A. Research grants were awarded in 2011 and 2012 (see list in General Assembly minutes).

B. Ethics guidelines for research were approved by the membership; these are a work in progress. 
X. VP for Communications report (K. Leighty)
A. Served as Program Chair for the 2012 Congress.
B. A new look was given to the Bulletin.
C. The "unsung primatologists" initiative has been advertised in four bulletins but no names have been put forth.
D. General concern that the membership does not read the Bulletin.

\section{Primate Specialist Group Report (C. Schwitzer)}
A. A full written report from International Union for Conservation of Nature (IUCN)/Species Survival Commission Primate Specialist Group (SSC PSG) will be available on the website.
B. Some important new taxonomic decisions include the splitting of Cebus into two genera (Cebus and Sapajus) and the addition of tarsier genera.
C. Lemurs are the most threatened of mammals.
D. The new list of the 25 most endangered primates will be discussed at this congress.

\section{International Journal of Primatology Report (J. Setchell)}
A. Impact factor went down from 1.8 to 1.5. Reasons are unclear.
B. Open access? This would be the publisher's decision.
C. Authorship is increasingly international.
D. Primatologists will be asked what they believe to be the "big unanswered questions" in primatology; a committee will refine the list of suggestions and put forth a "top ten" for which review articles will be solicited.
E. Editor Setchell asks that all IPS members submit their best work to IJP.

\section{Reports from Affiliated Societies}

A. Primate Society of Great Britain (P. Honess). PSGB continues to hold two meetings a year; continues to award captive care and conservation grants; the theme of the 2012 winter meeting will be biogeography.

B. European Federation of Primatologists (U. Radespiel). Meetings are held every other year. EfP met in Portugal in 2011 and will meet in Belgium in 2013. New EU directives on animal use are to be implemented by EU countries in Jan 2013 and are the subject of much discussion and debate by European primatologists.

C. Gesellschaft für Primatologie (U. Radespiel). GfP meets every other year, opposite IPS. The Society, which currently has 229 members, gives thesis awards and stipend awards for field work. GfP is working on zoo animal husbandry guidelines, trying to make the minimum standards higher. The Society also has a primates in entertainment policy statement.

D. Associação Portuguesa de Primatologia (C. Casanova). Established in 2004, the APP has about 50 members. It hosted the most recent EFP meeting and is considering hosting IPS sometime in near future. In 2013 the APP, together with APE (Associacion Primatológica de Española) will be organizing the 4th Iberian Primatological Congress in Spain (10th APE Congress and the 6th APP Congress). 
E. Sociedade Brasileira de Primatologia (M. Adelia B. de Oliveira and M. Talebi) has as many as 150 members. They expect about 50 people from Brazil at this congress, which is a record. They will host the upcoming Latin American primatology meeting in Recife.

F. American Society of Primatologists (D. Fragaszy). The 2013 meeting will be in Puerto Rico, celebrating the 75th anniversary of the Caribbean Primate Research Center. This year ASP will hold its first competition for a newly established fellowship for interdisciplinary research. The report by the Institute of Medicine (USA) on use of chimpanzees in research was accepted by the National Institutes of Health (USA). ASP submitted a commentary to help define the term "ethologically appropriate," which is used in the report.

G. Associazione Primatologica Italiana (M. Gamba). API met in Verona in 2011 and had international attendance. They, like other European societies, are dealing with EU directives, and they are trying to help reduce the illegal importation of primate pets. API uses its funds to support student travel to conferences. They will meet again in 2013.

H. Asociación Mexicana de Primatología (G. Ramos-Fernandez). Established in 1987, it currently has 13 paid members and became an affiliate at the Kyoto Congress. AMP is helping to revive a Latin American primatology meeting schedule. AMP is trying to find ways to influence the Mexican government in conservation efforts and establishing priority areas for conservation. They have produced a documentary about Mexican primates using a professional filmmaker.

I. Primate Society of Japan (J. Yamagiwa). PSJ has about 540 members. It thanks primatologists around the world for aid following the tsunami. PSJ is beginning to study the effects of the disaster on the macaques, and the news thus far is good in terms of numbers surviving. Every year PSJ gives funds to students to go to an international meeting. This year, one Japanese student is in Cancun for the congress.

J. Primate Ecology and Genetics Group, South Africa (R. Sithaldeen). PEGG had its 10th annual meeting this year. Fifty people attended, from a variety of countries. PEGG fights an ongoing battle with the government about the status of baboons and vervets, which are considered to be pests. PEGG has an active web page and newsletter.

\section{Preliminary bid for IPS 2016 (N. Caine for S. Ross)}

A. Steve Ross of the Lincoln Park Zoo has submitted a bid to host the 2016 meeting in Chicago, Illinois, USA.

B. It is likely to be held in late August and is likely to be a joint meeting with the American Society of Primatologists.

C. The Council voted unanimously to accept the bid pending the completion of the bid details.

XV. IPS was asked to meet with a representative of the British Union of Antivivisectionists regarding the international distribution of our captive care 
guidelines. Debby Cox, Christoph Schwitzer, Janette Wallis, and Juichi Yamagiwa will do so at this congress, if possible.

The meeting was adjourned by President Yamagiwa at 17:43 h.

\section{Minutes from the General Assembly of the International Primatological Society August 17, 2012}

I. Call to order and President's remarks (J. Yamagiwa)

A. A moment of silence was taken for primatologists who have passed away since the Kyoto Congress.

B. Sincere thanks were given to the organizing committee of the 2012 Congress. It was a very successful and well-run meeting.

C. On behalf of the Organizing Committee (Aralisa Shedden, Secretary; Jorge Martinez-Contreras, President; Ernesto Rodrigues-Luna, co-President), Drs. Martinez-Contreras and Rodrigues-Luna thanked the Congress staff and volunteers.

II. Summary of Council Reports (N. Caine)

A. Secretary General Caine reminded the membership that the IPS Council meets twice at every congress, once at the beginning and once at the end, to carry out the business of IPS. The IPS Council includes the officers (President, Secretary General, Treasurer, and the immediate Past President who serves as the ad hoc member), the Vice Presidents (Captive Care, Communication, Conservation, Education, Membership, Research), a representative from the IUCN Primate Specialist Group, and representatives of each of the affiliated societies of IPS.

B. Reports by members of Council were given at the pre-congress meeting. Details from those reports can be read in the meeting minutes, which will appear in the next issue of the IPS Bulletin and, eventually, in IJP.

C. At the pre-congress Council meeting, a preliminary bid to host the 2016 Congress in Chicago was presented by Dr. Steve Ross of the Lincoln Park Zoo. It will likely be a joint meeting with the American Society of Primatologists in late August/early September. Dr. Ross came to the podium to give a brief presentation.

D. There were no actions taken by the Council that required action by the General Assembly. However, the Council had a long discussion, in conjunction with the Treasurer's report, about the costs of attending congresses and the financial well-being of the IPS. At the conclusion of that discussion the following motion was unanimously passed:

The IPS Council will communicate with affiliated societies that:

a. It understands and shares concerns about the costs of attending congresses, especially for students and primatologists from range countries. 
b. IPS and local organizing committees will continue to work to set congress costs as low as possible, recognizing that many of the costs are out of our control (travel, accommodations, food, fixed venue costs, etc.).

c. All congress budgets are designed to break even, but when profits are realized IPS is able to fund our grants and training programs; indeed, increased funding to our grants and training programs has followed profitable congresses.

d. The Society is exposed to financial risk associated with the biannual congress. The IPS Council recognizes that it is the Council's responsibility to maintain the fiscal health of the IPS by maintaining a financial reserve to cover unexpected losses associated with congresses. About $50 \%$ of the cost of a typical congress should be maintained as a reserve, when possible.

\section{Membership and Finance Reports (S. Schapiro)}

A. PowerPoint slides depicted changes in membership over the past two years. Membership is at about the 2008 level, down by about 250 members since the 2010 Congress.

B. IPS gives out about $\$ 85,000$ in grants and awards each year.

C. Congresses are always planned on a "break-even" basis. Registration fees reflect the total cost of running the congress divided by the number of expected registrants.

D. Unexpected profits made at the 2006 and 2008 Congresses, along with the initial round of Lifetime Memberships, provided a financial "nest egg" that is held in savings to guard against losses that might be incurred in association with future congresses.

E. Based on prior congresses we estimated that 1000 people would attend IPS in Cancun. Only 650 registered, however, and thus IPS will sustain a loss of about $\$ 60,000$ this year.

F. The projected balance in the General Fund at the end of 2012 is about $\$ 100,000$.

\section{Research Grants (J. Setchell)}

A. The following individuals were awarded grants by the Research Committee in 2011. Those with an asterisk were also given Community Conservation Initiative funds: Caitlin Barale - USA*; Mackenzie Bergstrom - Canada; Maryjka Blaszczyk - USA; Debapriyo Chakraborty - India; Sofia Forss Switzerland*; Cecile Garcia - France; Jess Hartel - USA; Luca Pozzi USA; Nicoletta Righini - USA; Rebecca Wyper - UK.

B. The following individuals were awarded grants by the Research Committee in 2012. Those with an asterisk were also given Community Conservation Initiative funds: Glowacka Halszka - USA; Mariana Raño - Argentina; Jessica Walz - USA; Jackson Frechette - USA*; Sheena Faherty - USA; Tara Mandalaywala - USA; Amanda Perofsky - USA 
V. Education Awards (E. Lonsdorf)

A. In 2011, Jacobsen Awards were given to Tammie Bettinger - US (working in DRC)*; Vicky Melfi - UK (working in Sulawesi); Sian Waters - UK (working in Morocco); Victor Wodi - Indonesia (working in Sulawesi)*; Kefing Niu - China (working in China); Corrin LaCombe - USA (working in Vietnam); Alejandra Duarte - Mexico (working in Mexico). Those with an asterisk were also given Community Conservation Initiative funds.

B. In 2012, Jacobsen Awards were given to Stella de la Torre - Ecuador (working in Ecuador); Julie Ghrist - USA (working in Rwanda); Sonya Kahlenberg - USA (working in Uganda); Daniel Mwamidi - Kenya (working in Kenya).

C. In 2011, Soutwick Awards were given to Joseph Karama - Rwanda (working in Rwanda) and Mariamah Achmad - Borneo (Gunung Palung Orangutan Conservation Program).

D. In 2012, a Southwick Award was given to Jacob Willie - Cameroon (working in Cameroon).

VI. Captive Care Grants (D. Cox)

A. The following individuals were awarded grants by the Captive Care Committee in 2011. Those with an asterisk were also given Community Conservation Initiative funds: Andrea Edwards - Australia (working in DRC)*; Claire Coulsen - UK (working in Nigeria); Jasper Lepema Netherlands (working in Zambia)*; Pablo Stevenson - Colombia (working in Colombia); Raeffaella Commitante - USA (working in Indonesia); Steven Unwin - UK (working in Uganda); Tilo Nadler - Germany (working in Vietnam).*

B. The following individuals were awarded grants by the Captive Care Committee in 2012. Those with an asterisk were also given Community Conservation Initiative funds: Alison Grand - USA (working in the DRC)*; Alejandra Duarte - Mexico (working in Mexico); Natalia Ceballos Venezuela (working in Venezuela)*; Jasper Lepema - Netherlands (working in Malawi)*; Nicolien Shoneveld-de Lange - Netherlands (working in Nigeria)*; Susan Lutter - US (working in Zambia); Raeffaelia Commitante US (working in Malaysia).

VII. Conservation Grants and Awards (J. Wallis)

A. The following individuals were awarded conservation grants in 2011. Those with an asterisk were also given Community Conservation Initiative funds: Jessica Moody - USA (working in Cambodia); Julia Hill - UK (working in Cambodia); Noga Shanee - Israel/Germany/UK (working in Peru); Dilip Chetry and Randy Kyes - India (working in India); Laetitia Marechal France/UK (working in Morocco); Claire Coulson - UK (working in the Nigeria)*; Julie Wieczkowski - USA (working in Kenya)*; Muhammad Subarkah - Indonesia (working in Indonesia); Joao Pedro Souza-Alves - 
Brazil (working in Brazil); Rebecca Wyper - UK (working in Indonesia); Jenna Wehr - USA (working in Madagascar)*.

B. The following individuals were awarded conservation grants in 2012. Those with an asterisk were also given Community Conservation Initiative funds: Pierre Fidenci - USA (working in the Philippines)*; Sydney Ndolo - Congo (working in the Congo); Nicolien Shoneveld-de Lange - Netherlands (working in Nigeria)*; Donald Mbohli - Cameroon (working in Cameroon)*; Sian Waters - UK (working in Morocco)*; Brianne A. Beisner - USA (working in India); Drew T. Cronin - USA (working in Equatorial Guinea); David Ehlers Smith - UK (working in Borneo).

C. The Martha Galante Award for 2011 was given to Didier Abavandimwe of Rwanda. The Martha Galante Award for 2012 was given to Vanina Alejandra Fernandez of Argentina.

\section{Pre-Congress Training Program 2012 (J. Wallis)}

A. Participants: Alongamoh Nkemanteh Edwin - Cameroon; David Osei Ghana; Ika Yuni Agustin - Indonesia; Tran Van Bang - Vietnam; Agnes H. Budisaputri - Indonesia; Maria Isabel Estevez Noboa - Ecuador; Javier Enrique Garcia Villalba - Colombia; Mariana Bueno Landis - Brazil; Julio Cesar Tello Alvarado - Peru; Hilda Maria Diaz-Lopez - Mexico; Francisca Fidal-Garcia - Mexico; Braulio Pinacho-Guendulain - Mexico.

B. The following individuals were accepted for the PCTP but were unable to attend: Henry Didier Camara - Guinea; Phillip Kihumoro - Uganda; Ummay Habiba Khatun - Bangladesh.

C. Mentors/Lecturers: Janette Wallis - USA; Mauricio Talebi - Brazil; Sonia Sanchez - Spain; Richard Bergl - USA; Ernesto Rodriguez-Luna - Mexico. Logistical support: Cristina MacSwiney - Mexico.

D. Special thanks to Alejandra Duarte for her selfless service to the PCTP this year.

E. The participants received valuable training not only in matters directly related to conservation, but also in new technologies (e.g., GPS), writing grant proposals, etc. Each trainee received a thumb drive with program materials included. The goal of the PCTP is not only for the trainees to return to their countries and implement conservation actions, but also to train their local colleagues and students.

F. A brief video was shown that described the goals of PCTP and the participants in 2012.

\section{International Journal of Primatology (J. Setchell)}

A. IJP attracted 204 new submissions in 2011, and is on track for a similar submission total in 2012 .

B. Impact factor went down from 1.8 to 1.5. The reasons for this are unclear.

C. Authorship is increasingly representative of the international scope of our field, with a higher percentage of authors from Asia, Latin America, and Africa than ever before. 
D. To set the agenda for future research, Editor Setchell is soliciting the "Top Ten Big Questions” in primatology (top.10.big.questions@gmail.com ). These will be discussed and voted upon, and review articles will be solicited for publication in IJP.

X. Student Competition winners (E. Lonsdorf)

A. The following students were selected as delivering the best papers at the Cancun Congress:

1. First place: Katie Amato - "Spatial and temporal patterns in Mexican black howler (Alouatta pigra) gut microbial community composition."

2. Second place: Jessica Bryant - "Conserving the world's rarest ape: investigating the factors constraining the recovery of the Hainan gibbon (Nomascus hainanus)."

3. Honorable Mention: Victoria Wobber - "Bonobos and chimpanzees differ in their rapid steroid shifts during competition."

B. The following students were selected as giving the best posters at the Cancun Congress:

1. First place: Caroline Wardrop - "Using population viability analysis to assess threats and predict the potential for long-term survival of the northern white-cheeked crested gibbon (Nomascus leucogenys) in Vietnam."

2. Second place: Erin Hecht - "Does the chimpanzee brain 'mirror' observed actions? Functional neuroimaging during action execution and observation."

C. Cash prize from IPS for the winners: $\$ 350$ for first place, $\$ 250$ for second place, and $\$ 150$ for honorable mention. Also, book prizes are given by Cambridge University Press.

\section{2014 Congress: Ha Noi, Vietnam (Nguyen Manh Hiep)}

A. The congress will be held August 11-16 at the Melia Ha Noi Hotel.

B. A website, primatecongress2014.vn, will be available in October 2012.

C. In addition to the scientific program, congress attendees will be able to enjoy a variety of pre- and/or post-congress tours to enjoy the wildlife and cultural history of the country.

XII. Business from the floor

A. Concerns were expressed from a number of members about the inability of students and scientists from range countries to attend IPS congresses due to financial constraints. Some suggestions were made:

1. Giving travel awards instead of so many research grants

2. Tapping into new and old sources of charitable giving

3. Holding regional meetings in range countries 
4. Holding congresses on college campuses, assuming those are less expensive locations

5. Establishing a VP for Fund Raising

B. We were invited to participate in the effort to have Jane Goodall considered for a Nobel Peace Prize.

C. It was suggested that the IPS financial report be posted to the IPS website in advance of the congress.

D. It was suggested that the membership be surveyed as to reasons why members do or do not attend congresses.

E. An invitation was received from Mr. Doug Cress for IPS to join GRASP as a partner.

F. A request was made by Drs. Bob Cooper and Sian Evans that IPS write a letter of support for the actions of the Colombian courts in halting illegal trade in Aotus.

XIII. Thanks to outgoing officers and installation of new officers (J. Yamagiwa)

A. VP for Captive Care, Debby Cox, and VP for Communications, Katie Leighty, were issued our sincere appreciation for their service. Special note was made of the fact that Dr. Leighty has served IPS as a Vice President for many years and has made a tremendous impact on the Society.

B. Incoming President Tetsuro Matsuzawa, incoming VP for Captive Care Christoph Schwitzer, and incoming VP for Communications Claudia Fichtel (not present) were invited to the podium as the outgoing officers, including Juichi Yamagiwa, stepped down.

XIV. President Matsuzawa remarked that he hopes to promote "The Three Cs" in his term of office: Continuity, Collaboration, and Commitment to the IPS. He adjourned the meeting at about 19:00 h.

Minutes from the Post-Congress Meeting of the Council of the International Primatological Society August 18, 2012

Attending:

IPS Officers:

Tetsuro Matsuzawa (President)

Juichi Yamagiwa (ex-officio; immediate Past President, also representing Primate Society of Japan)

Nancy Caine (Secretary General)

Katie Leighty (for Claudia Fichtel, VP for Communications)

Elizabeth Lonsdorf (VP for Education)

Debby Cox (for Christoph Schwitzer, VP for Captive Care and Breeding)

Steve Schapiro (Treasurer and VP for Membership)

Janette Wallis (VP for Conservation)

Jo Setchell (VP for Research and Editor-in-Chief of IJP) 
Affiliated Society Representatives:

Sonia Sanchez Lopes (Asociación Primatológica Española)

Paul Honess (Primate Society of Great Britain)

Dorothy Fragaszy (American Society of Primatologists)

Renata Ferreira (Sociedade Brasileira de Primatologia)

Riashna Sithaldeen (Primate Ecology and Genetics Group, South Africa)

Ute Radespiel (Gesellschaft für Primatologie \& European Federation of Primatologists)

Lilian Cortés Ortiz (Asociación Mexicana de Primatología)

I. The meeting was called to order at 09:00 h by President Matsuzawa.

A. Introductions were made.

B. The President reiterated his message, given at the General Assembly, that the "Three Cs" should guide the IPS over the next four years: Continuity, Collaboration, and Commitment.

II. Remarks from Secretary General Caine

A. New officers should read, and continuing officers should re-read, the Constitution and By-laws to be sure they understand their duties

B. Affiliate societies should carefully read Article 13 of the Constitution regarding their eligibility for affiliate status and voting privileges on the IPS Council.

C. The 2014 Congress in Ha Noi is progressing.

1. It will be important for members of the Council to serve active roles on the program, local arrangements, PCTP, and other important subcommittees.

a. Janette Wallis agreed to be the IPS coordinator of the PCTP.

b. Steve Schapiro will be the IPS coordinator of local arrangements.

2. Steve Schapiro will likely travel to Ha Noi next year to meet with the organizers and see the venues.

D. The 2016 Congress in Chicago

1. The bid was provisionally accepted at the pre-congress Council meeting, pending additional information.

2. Results of discussions with ASP (with which IPS will likely meet jointly) about dates are forthcoming.

3. The complete bid will be submitted this fall and if all goes as planned, Council will vote to change its provisional status to "accepted."

III. Issues from the General Assembly

A. There was a request from Robert Cooper and Sian Evans to send a letter of support for actions taken in Colombia to protect Aotus. 
1. IPS has no way of independently investigating such matters, nor is it a regulatory agency.

2. However, we agreed that it would be proper for us to write in support of the Colombian courts' actions in enforcing that country's laws regarding wildlife.

3. Sec. Caine will compose the letter, to go out over Pres. Matsuzawa's signature.

B. Concerns were expressed about the isolation of African students and scientists and their absence at IPS congresses.

1. Council does not support the idea of returning to the regional secretaries concept that was voted out by the membership years ago.

2. VP Wallis will provide contact information for existing groups of primatologists across Africa (e.g., Primate Ecology and Genetics Group (PEGG), Pan African Sanctuary Alliance (PASA), Great Apes Survival Partnership (GRASP), and Groupe d'Etude et de Recherche sur les Primates de Madagascar (GERP), etc.) so they can build greater communication and discuss the possibilities for regional meetings.

3. A notice will be sent to the list serve that invites African primatologists to contact VP for Communications Fichtel for more information about ways in which interested members or groups can become more involved in IPS.

4. A motion was passed that President Matsuzawa will form an ad hoc committee to discuss ways to improve regional representation at congresses and in IPS in general. This includes greater roles for affiliate societies.

C. Should IPS become a member of GRASP?

1. The general membership will be asked to vote on this.

2. A list of pros and cons associated with GRASP membership will be developed by VP Wallis and forwarded to the IPS membership via the list serve prior to the vote.

D. Is the Galante Fund being used as intended? VP Wallis will investigate the history of the fund.

IV. Other action to be taken by IPS

A. Web pages will be updated and provide more history about IPS. Additional links will be added.

B. The financial report will be available via the website prior to the congress.

C. An ad hoc committee, chaired by Secretary Caine, will review the IPS Constitution and By-laws to bring our activities in line with our rules, or to propose changes that bring the rules in line with practice.

D. VP Schapiro will work out a way to confirm gratis membership on an annual basis such that members are aware that they can ask to renew their free membership. 
E. VPs Wallis and Schwitzer will look into the possibility of IPS involvement in CITES (Convention on International Trade in Endangered Species) meetings.

F. Pres. Matsuzawa will confer with Russ Mittermeier about IPS involvement in CBD (Convention on Biological Diversity).

The meeting was adjourned at about 13:00 h. 